\title{
ПРОФЕСІЙНА КУЛЬТУРА ЮРИСТІВ: ПОНЯТТЯ, СУТНІСТЬ І ФАКТОРИ ФОРМУВАННЯ
}

\author{
Бурдоносова М. А.
}

Lex autem non est sine iure quis meliorem cotidie. Digests of Justinian ${ }^{1}$

\section{ВСТУП}

На шляху євроінтеграції перед Україною постають питання посилення законності та правопорядку, забезпечення надійної охорони конституційних прав i законних інтересів громадян, профілактики правопорушень, які є невіддільними від модернізації, прискорення соціально-економічного реформування, боротьби з корупцією та підвищення культурного рівня населення. Важливу роль у цих процесах відіграють юристи, які забезпечують їх правове регулювання та застосування норм права. Це зумовлює необхідність комплексного дослідження наукових і практичних проблем професійної культури юристів.

Діалектика будь-якого наукового пізнання, і правова сфера не виняток, полягає в тому, що розширення й поглиблення розроблюваного питання спричиняють переосмислення й аналіз на новому, більш високому, рівні вихідних даних і передумов дослідження. Отже, поглиблення досліджень професійної правової культури може зробити суттєвий внесок у теорію правової культури та культури суспільства загалом, особливо враховуючи той факт, що перед сучасними дослідниками у сфері юридичної деонтології, теорії держави і права, юридичної психології, правової культури постають питання комплексного аналізу взаємозв'язку правового пізнання, правосвідомості, юридичної практичної діяльності та правореалізації.

У юридичній літературі різноманітні аспекти дослідження професійної правової культури розглядали в працях такі вчені, як С.В. Аграновська, О.А. Ануфрієнко, В.О. Безбородий, М.А. Бурдоносова, А.Б. Венгеров, Ю.М. Грошевий, С.Д. Гусарєв, А.Е. Жалінський, І.П. Зеленко, І.О. Ільїн, М.I. Козюбра, М.В. Костицький, В.О. Котюк, О.Б. Костенко, В.В. Лазарєв, Л.О. Макаренко, П.В. Макушев, Н.М. Оніщенко, М.В. Орзіх, О.Р. Ратінов, В.П. Сальніков, А.П. Семітко, М.Я. Соколов, С.С. Сливка, В.Я. Тацій, О.Д. Тихомиров, Т.О. Чепульченко, Б.О. Чупринський та ін.

\footnotetext{
${ }^{1}$ Право не може існувати без правознавців, які щодня вдосконалюють його (Дигести Юстиніана).
} 
Важливість звернення до питань професійної культури юристів пов'язана 3 тим, що підвищення ролі права в процесі розбудови демократичної, соціальної, правової держави і становлення громадянського суспільства висуває підвищені вимоги до обгрунтування вченими-юристами базових методологічних позицій і засобів наукового пізнання. Крім того, сучасна юридична наука, виробивши нові прийоми та способи дослідження, потребує більш чіткої організації діяльності вчених-юристів 3 метою ефективного використання отриманих ними даних на практиці.

Дослідження професійної культури юристів становить інтерес і з погляду 3'ясування специфіки формування, функціонування та розвитку культури великої соціальної групи в державі, об'єднаної суттєвими професійними інтересами. Важливо враховувати й той факт, що відсутність у юристів правової культури не лише ускладнює боротьбу з правопорушеннями, а й може стати однією з причин їх скоєння.

Чітке 3'ясування стану та рівня зрілості професійної культури юристів необхідна умова ефективної правової політики, оскільки, які б не були ідеальні закони держави на папері, утілюють їх у своїх діях люди. А на юристів із цього погляду покладена подвійна місія: не лише зразкового застосування правових норм, а й професійного відстеження їх чіткого дотриманням іншими.

\section{1. Поняття й сутність професійної культури юристів}

Невід'ємним складником успішного реформування та подальшого стійкого розвитку українського суспільства $є$ правове забезпечення цих процесів. Воно передбачає ефективне правове регулювання суспільних відносин, удосконалення чинного законодавства в рамках євроінтеграції, посилення боротьби зі злочинність. Злагоджене функціонування всіх елементів механізму правового регулювання суттєво залежить від професійної правової культури юристів. Їх можна порівняти з годинниковим майстром, що слідкує за роботою механічного годинника: поламка однієї з деталей призводить до розбалансування всієї системи.

Юридична енциклопедія визначає правову культуру як систему духовних і матеріальних цінностей права, що є складником загальної культури й охоплює всю сукупність найважливіших ціннісних компонентів правової реальності в ії розвитку, є однією з категорій загальнолюдських цінностей $\mathrm{i}$ невід'ємним компонентом правової держави.

В аспекті логічної структури правова культура становить об'єктивні за своїм змістом знання про державу і право. За глибиною цих знань виділяють звичайний і професійний (спеціальний) рівні. Перший із них обмежується загальними знаннями людей про правові явища. Другий формується в осіб, 
які спеціально займаються правовою діяльністю (юристів). Останнім властиві більш глибокі юридичні знання².

Правова культура юристів $є$ одним із видів групової професійної культури, яка $є$ складовим елементом правової культури суспільства загалом, а ключовим критерієм виокремлення цієї соціальної групи $\epsilon$ професійна належність. Термін «професійна» підкреслює більш якісний рівень праці та характер ставлення соціальної групи чи особи до власної трудової діяльності, яка є основним джерелом доходу.

У науковому розумінні професійна правова культура - це правова культура, носіями якої є правники, котрі професійно займаються юридичною діяльністю. Виходячи із цього твердження, для інших соціальних груп правова культура не виступає як професійна. Для інших категорій професійною буде, наприклад, науково-педагогічна культура для викладача, медична культура для лікаря, управлінська культура для державного службовця тощо, оскільки вона визначається специфікою їхньої професії. Необхідно додати, що в сучасному суспільстві представники будь-якої професії мають певний рівень правової культури, однак вона не є для них професійною. Наприклад, можна говорити про специфіку правової культури журналіста, менеджера, бухгалтера, але не можна стверджувати, що вона саме професійна.

Важливим аспектом поняття професійної правової культури $\epsilon$ чітке визначення осіб, які є їі носіями. У загальному розумінні це юристи (від лат. jus (juris) - право), тобто особи, які мають юридичну освіту, правознавці ${ }^{3}$. Цим узагальненим поняттям охоплюються судді, прокурори, працівники поліції (наприклад, слідчі, дізнавачі), адвокати, юрисконсульти, що працюють на підприємствах, в установах, організаціях і юридичних фірмах, ученіправознавці, викладачі права. Близьким до терміна «юрист» $є$ поняття «правник». Бачимо, що в науковому визначенні особливий акцент робиться на освітній підготовці. Однак, оскільки сутність професії визначається змістом юридичної діяльності, основною ознакою віднесення особи до тієї чи іншої професійної групи $є$ не стільки освіта, скільки здійснення конкретної діяльності. Тому доцільним буде вважати юристом не лише особу 3 юридичною освітою, правознавця, а й практичного діяча у сфері права. Для останнього освіта за фахом стане водночас й умовою прийняття на роботу, підвищення на посаді, допущення до участі в конкурсі тощо, звісно ж, не применшуючи при цьому значення юридичної освіти як теоретичної основи для майбутньої практичної діяльності та базису формування професійної правової культури.

\footnotetext{
${ }^{2}$ Юридична енциклопедія : у 6 т. / редкол. : Ю.С. Шемшученко та ін. Київ : Укр. енцикл. ім. М.П. Бажана, 1998-2004. Т. 5 : П-С. С. 37.

${ }^{3}$ Великий енциклопедичний юридичний словник / за ред. акад. НАН України Ю.С. Шемшученка. 2-ге вид., переробл. і доповн. Київ : Юридична думка, 2012. С. 1011.
} 
Н.Я. Соколов визначає сутність юридичної професії як рід діяльності, пов'язаний із правовим регулюванням суспільних відносин, забезпеченням дотримання учасниками суспільства правових норм, що потребує необхідних знань і навичок, які можна набути в результаті юридичної освіти й (або) практичного досвіду, і покладає на юриста відповідальність за ефективне виконання професійних обов'язків у системі суспільного розподілу праці ${ }^{4}$. Погоджуючись із М.Я. Соколовим, варто додати, що виокремлення та функціонування професійно-юридичної групи засновано на реальних відносинах, що є характерними для будь-якої соціальної групи: єдність інтересів, спільна мета діяльності, взаємодія між учасниками.

3 урахуванням специфіки професійної юридичної культури вагомого значення набувають такі ії сутнісні риси:

1) правові цінності;

2) рівень правової свідомості;

3) способи практичної діяльності юристів;

4) якісний стан правового життя юридичної спільноти;

5) юридична освіта.

Правова культура загалом, а також професійно-правова як ії складник передбачає наявність в особи правових иінностей, серед яких першочергову роль відіграє усвідомлене розуміння цінності самого права. Власне, під цінністю права прийнято розуміти його здатність слугувати метою та засобом для задоволення соціально справедливих потреб індивідів і суспільства загалом, стверджувати гуманні засади у взаємовідносинах особи й влади, бути силою, яка протистоїть сваволі (наприклад, узурпації влади, етатизації суспільства чи саморозправі). Соціальна цінність (корисність) права полягає в тому, що воно надає людині організованості, стійкості, погодженості, забезпечує певну стабільність і впевненість у майбутньому. Право тим самим уносить елементи упорядкування в суспільні відносини, $є$ засобом їх цивілізованості ${ }^{5}$. Цінність права формується в кожної людини (особистісна цінність), соціальних спільнот та об'єднань (групова цінність) i, зрештою, суспільства загалом (загальносоціальна цінність). Розуміння позитивної значущості права притаманне як загальносоціальному рівню: таке право виникає й існує незалежно від держави, зокрема права людини, права нації, так і спеціально-соціальному (юридичному) праву, що є волевиявленням держави, обов'язковим для виконання'

\footnotetext{
${ }^{4}$ Соколов Н.Я. Юридическая профессия: понятие: сущность и содержание. Государство и право. 2004 № 9. C. 22-30.

${ }^{5}$ Оніщенко Н.М. Сприйняття права в умовах демократичного розвитку : проблеми, реалії, перспективи : монографія / відп. ред. Ю.С. Шемшученко. Київ : Юридична думка, 2008. С. 274.

${ }^{6}$ Юридична енциклопедія : у 6 т. / редкол. : Ю.С. Шемшученко та ін. Київ : Укр. енцикл. ім. М.П. Бажана, 1998-2004. Т. 1 : А-Г. С. 74.
} 
Засвоєння юристами правових цінностей дає їм змогу приймати правильні рішення, співвідносити свої права й обов'язки із законними інтересами інших осіб. Наприклад, відповідно до ч. 1 ст. 94 Кримінального процесуального кодексу України, слідчий, прокурор, слідчий суддя, суд за своїм внутрішнім переконанням, яке грунтується на всебічному, повному й неупередженому дослідженні всіх обставин кримінального провадження, керуючись законом, оцінюють кожний доказ з погляду належності, допустимості, достовірності, а сукупність зібраних доказів - 3 погляду достатності та взаємозв'язку для прийняття відповідного процесуального рішення ${ }^{7}$. Внутрішне переконання $\epsilon$ комплексним поняттям, однак беззаперечними його складниками є правосвідомість, заснована на правових цінностях, правова культура та моральна свідомість - совість.

У правовій системі Європейського Союзу, а також законодавстві державчленів СС є поширеним розуміння внутрішнього переконання як єдності трьох принципів - розумності, справедливості й добросовісності. Варто відзначити, що «добросовісність» $є$ досить універсальною категорією в праві й часто використовується для позначення критерію поведінки суб'єкта правової системи. Такий критерій вивчення доказів також можна знайти й у правилах арбітражного трибуналу Стокгольмської торгової палати 8

Професійні юристи, з одного боку, беруть участь у створенні правових цінностей у процесі правотворчої діяльності шляхом висування правових ідей, розробки проектів НПА, їх тлумачення тощо, а з іншого - $є$ їх носіями та охоронцями, оскільки в правових цінностях сконцентрований практичний досвід багатьох попередніх поколінь юристів.

Глибинність перейняття деяких правових норм від попередніх поколінь можна простежити на прикладі рецепції римського права. Традиційно з часів римського приватного права зачата, але ненароджена дитина мала визначений правовий статус. На межі II-III століть римський юрист Тертулліан писав, що той, хто буде людиною, - уже людина. За законом Юлія Веллея (28 року), для охорони прав людського ембріона йому на прохання вагітної матері призначався піклувальник, уповноважений здійснювати управління майном, яке має успадкувати дитина в разі народження9.

Через 2000 років чинне цивільне законодавство України фактично рецепіювало вищезазначені положення римського права шляхом закріплення

\footnotetext{
${ }^{7}$ Кримінальний процесуальний кодекс України від 13.04.2012 № 4651-VI. База даних «Законодавство України» / Верховна Рада України. URL: https://zakon.rada.gov.ua/go/4651-17 (дата звернення: 01.11.2020).

8 Правила Арбітражного інституту Стокгольмської торговельної палати від 01.01.1988. База даних «Законодавство України» / Верховна Рада України. URL: https://zakon.rada.gov.ua/go/752_050 (дата звернення: 01.11.2020).

${ }_{9}^{9}$ Калітенко О.М. Окремі проблеми правового статусу насцитуруса за чинним законодавством України. URL: http://dspace.onua.edu.ua/bitstream/handle/11300/7992/ilovepdf_com-7-9.pdf?sequence=1\&isAllowed=y (дата звернення: 02.11.2020).
} 
в ч. 2 ст. 25 Цивільного кодексу України норми, згідно з якими у випадках, установлених законом, охороняються інтереси зачатої, але ще ненародженої дитини ${ }^{10}$ за умови, що вона народиться живою.

Отже, розуміння сутності професійної культури юристів як міри засвоєння та застосування правових цінностей пов'язано 3 певним рівнем розвитку їх правової свідомості й поведінки. Чим глибше юрист усвідомлює позитивну сутність правових явищ, тим ефективніше він орієнтується в проблематиці та бере активну участь на всіх стадіях правового регулювання. Зауважимо, що мова йде саме про високий рівень розвитку правової свідомості та правової культури юриста як зразка для наслідування й носія найвищих правових цінностей. Деформації аксіологічної правової свідомості, протиправну діяльність не варто включати до сутності правової культури.

Утілення юристами правових цінностей у своїх діях $\epsilon$ ще одним складником сутності правової культури. Тут варто робити наголос саме на активних діях і професійно-активній поведінці. Як відомо, за суб'єктивною стороною правова поведінка поділяється на звичну, конформістську, маргінальну й активну, остання є найкращим ii проявом. I від юриста суспільство очікує саме активної правової поведінки, заснованої на глибокому усвідомленні, переконанні в необхідності здійснення правомірних дій, зокрема в професійній діяльності (надання правової допомоги, роз'ясненні, консультуванні).

Сутнісною ознакою професійної культури юриста є творчий характер його діяльності. У сучасних умовах, коли суттєво зросли очікування з боку суспільства щодо роботи суддів і правоохоронних органів, на цій ознаці варто особливо наголошувати при підготовці фахівців у юридичних закладах вищої освіти. Першопочатковою стадією правового регулювання є правотворчість, тобто «творення права». Як зазначає М.Я. Соколов, ефективність цієї та інших стадій правового регулювання визначається не лише об'єктивними передумовами, а й станом юридичної науки, упровадженням у юридичну практику наукових рекомендацій і теоретичних розробок ${ }^{11}$.

Стан правової культури юристів проявляє себе на всіх стадіях правового регулювання. Професійна-правова культура передбачає глибокі, об'ємні та формалізовані знання джерел права, правильне розуміння принципів права, цілей і завдань правового регулювання, професійне ставлення до права та практики його застосування в суворій відповідності до вимог законності. Саме на такий високий рівень володіння правом у предметно-практичній діяльності й має бути спрямована сучасна юридична освіта.

\footnotetext{
${ }^{10}$ Цивільний кодекс України від 16.01.2003 № 435-IV. База даних «Законодавство Украӥни» / Верховна Рада України. URL: https://zakon.rada.gov.ua/go/435-15 (дата звернення: 02.11.2020).

${ }^{11}$ Соколов Н.Я. Профессиональная культура юристов. Понятие. Сущность. Содержание. Москва : Проспект, 2014. С. 15.
} 
Розуміння сутності професійної правової культури як міри засвоєння та використання правових цінностей пов'язано з якістю стану правового життя юридичного суспільства. Воно визначається соціальним статусом юристів, умовами їхньої праці, ступенем розвитку професійної демократії. Їх практичним вираженням стають рівень професійної діяльності та їі результати.

Показниками рівня якості й основними проблемами правового життя юридичного українського суспільства $є$ колізійний стан процесуального законодавства, надмірний формалізм у роботі судових і правоохоронних органів, конфлікт повноважень антикорупційних органів (в Україні це Національне антикорупційне бюро, Спеціалізована антикорупційна прокуратура, Національне агентство 3 питань запобігання корупції та Державне бюро розслідувань). Крім того, важливим показником стану професійної діяльності юристів $є$ ступінь державного гарантування умов для іiї якісного забезпечення. На жаль, рівень фінансування юридичної науки та освіти в Україні залишається незадовільним ${ }^{12}$.

Аналізуючи етимологію слова «юстиція» (від лат. «јustitia»), що означає справедливість, розуміємо, що в самому терміні закладено вимогу до юристів бути справедливими ${ }^{13}$. Саме тому неправові (наприклад, корупційні) дії, учинені представниками юридичних професій (суддями, прокурорами, слідчими), особливо болюче сприймаються суспільством, спричиняють розчарування в силі права, зневіру в законі, правовий нігілізм серед населення. Тому надзвичайно важливим $є$ питання усвідомлення юристами своєї відповідальності перед суспільством, підвищення вимог до їхньої професійної поведінки та діяльності, оскільки їхній професіоналізм, принципова позиція захисту суспільних інтересів, почуття соціальної відповідальності й незаплямована репутація є найкращими показниками позитивних змін і реформ, на які так очікує українське суспільство.

\section{2. Фактори формування професійної культури юристів}

Створення соціально-психологічного портрету сучасного юриста неможливе без дослідження рівня його правової культури, правосвідомості й мотивації професійної поведінки. У наявних наукових дослідженнях

\footnotetext{
12 За даними Організації економічного співробітництва та розвитку (Organisation for Economic Co-operation and Development), лідером рейтингу країн, які виділяють найбільше коштів на фінансування науки в процентах від ВВП, є Ізраїль. До ТОП-5 за рівнем фінансування науки, крім Ізраїлю, входять також Південна Корея, Тайвань, Швейцарія та Швеція. Понад $3 \%$ від ВВП на фінансування науки виділяють Японія, Австрія, Німеччина та Данія. Більш як 2\% від ВВП на розвиток науки виділяють у США, Фінляндії, Бельгії, Франції, Нідерландах, Китаї, Норвегії та Ісландії. На жаль, Україна до рейтингу не ввійшла. OECD.org. URL: https://chasdiy.org/news/iaka-kraina-vydiliaie-naibilshe-koshtiv-na-finansuvannia-nauky-oesr.html (дата звернення: 03.11.2020).

${ }_{13}^{13}$ Юридична енциклопедія : у 6 т. / редкол. : Ю.С. Шемшученко та ін. Київ : Укр. енцикл. ім. М.П. Бажана, 1998-2004. Т. 6 : Т-Я. С. 499.
} 
більше уваги приділялося розгляду правової культури окремих професійних груп: суддів, прокурорів, працівників національної поліції. Підтримуючи розпочаті більш загальні філософсько-правові дослідження в цьому напрямі $^{14}$, зазначимо, що все ж недостатньо висвітленими залишаються питання 3'ясування загальних закономірностей i факторів формування й розвитку професійної правової культури сучасних юристів.

При дослідженні зазначених аспектів професійної правової культури варто звернути особливу увагу на те, що це явище $\epsilon$ інтеграційним феноменом. Воно перебуває на зрізі правової науки, культурології, соціології, психології. Ураховуючи цю обставину, найбільш доцільною методологічною конструкцією дослідження видається така: спираючись на закони та категорії діалектики, використовуючи загальнонаукові методи юридичної науки, узяти за основу теоретико-правові категорії, уявлення, концепції закономірності юридичної науки, застосувати культурологічні, соціологічні, психологічні поняття й категорії.

Додатково при дослідженні професійної культури юристів варто враховувати подвійну природу основних понять і категорій. Окрім того, що науковий апарат включає юридичні поняття «право», «закон», «відповідальність», «обов'язок», «законність», «правопорядок», необхідно застосувати ще й культурологічні, соціологічні, психологічні поняття та категорії, такі як «цінності», «традиції», «поведінка», «діяльність», «соціальна група».

Урахування зазначеного співвідношення дасть змогу запобігти надмірній юридизації результатів дослідження й водночас уникнути значного викривлення в бік культурології або психології. Тобто особливої уваги дослідника потребує проблема синтезу юридичних і культурологічних понять, їх ознак та особливостей у єдиний комплекс, тому доцільним у дослідженні професійної культури юристів буде застосування комплексного, інтегративного підходу ${ }^{15}$.

Вище вже було зазначено, що професійна культура та правова свідомість юристів багато в чому збігаються 3 поняттям правової культури, що зумовлено правовою сферою їхньої професійної діяльності. Однак не варто повністю ототожнювати ці поняття. У їх співвідношенні можна виокремити фактори, що впливають на формування професійної культури юристів.

\footnotetext{
${ }^{14}$ Сливка С.С. Філософсько-правові проблеми професійної культури юриста : автореф. дис. ... докт. юрид. наук : 12.00.12 / Національна юридична академія України ім. Ярослава Мудрого. Харків, 2002. 32 с.

Чупринський Б.О. Формування професійної культури майбутніх юристів: філософсько-правове дослідження : автореф. дис. ... канд. юрид. наук : 12.00.12 / Львів. держ. ун-т внутр. справ. Львів, 2010.20 с.

Макаренко Л.О. Теоретико-методологічні аспекти пізнання та формування правової культури : дис. ... докт. юрид. наук : 12.00.01 / Інститут держави і права імені В.М. Корецького НАН України. Київ, 2019. 423 с.

15 Бурдоносова М.А. Методологічні особливості дослідження професійної культури юристів. Публічне право : науково-практичний юридичний журнал. 2015. № 4 (20). С. 263-264.
} 
Л.О. Макаренко зазначає, що правосвідомість $є$ властивістю психіки суб'єкта відбивати у відчуттях, уявленнях і думках об'єктивно існуючу правову дійсність і правову культуру як належність цієї дійсності. Як така правосвідомість не належить об'єктивній дійсності, а є атрибутом самого суб'єкта, у діяннях якого (правомірних або протиправних) вона себе виявляє як дійсна правосвідомість.

Правосвідомість $є$ практичним складником права, оскільки вона включається в процес створення й функціонування права в суспільстві правовою діяльністю суб'єктів, тобто реалізується в правовому процесі як суб'єктивний аспект правової діяльності. Лише в реалізації правосуб'єктності об'єктивно виявляється якість правосвідомості конкретного суб'єкта права, іï дійсний зміст для сприйняття його всіма іншими суб'єктами. Правова практика $є$ критерієм істинності не тільки правових знань, а й ціннісних оцінок кожною людиною правової дійсності - тих знань та оцінок, якими «заповнена» іiї правова свідомість ${ }^{16}$.

Як зазначають С.Д. Гусарєв, О.Д. Тихомиров, юристу для здійснення професійних обов'язків необхідно не тільки знати та розуміти право, складати документи, а й вільно і красиво викладати свої думки, елегантно одягатися, знати історію, філософію, політику, ввічливо та уважно спілкуватися 3 громадянами. Тобто потрібно володіти більш значною системою духовних цінностей, які становлять поняття загальної культури особи. У зв'язку з цим у структурі професійної культури юристів виділяють правову культуру, етичну, психологічну, моральну, естетичну, політичну тощо залежно від мети й конкретизації предмета дослідження ${ }^{17}$.

Перед тим як аналізувати фактори, що впливають на формування професійної свідомості та культури юриста, необхідно визначитися попередньо з тими завданнями, які постають перед ними в ході виховного процесу. Ідеться про наявність кінцевої мети - абстрактної моделі або теоретичної конструкції професійної свідомості юриста. Спробуємо сформулювати деякі положення й вимоги щодо такої моделі:

- у визначенні моделі професійної свідомості юристів фундаментальною основою та складовим елементом $\epsilon$ логіко-нормативний блок, до якого належать обсяг і глибина правових знань, рівень юридичного мислення. Знання права становлять конкретну вимірювальну категорію, мають свою структуру та поділяються на фундаментальні, галузеві, первинні та вторинні, знання про чинне право й окремі закономірності його функціонування;

\footnotetext{
16 Макаренко Л.О. Теоретико-методологічні аспекти пізнання та формування правової культури : дис. ... докт. юрид. наук : 12.00.01 / Інститут держави і права імені В.М. Корецького НАН України. Київ, 2019. С. 290.

${ }_{17}$ Гусарєв С.Д., Тихомиров О.Д. Юридична деонтологія (Основи юридичної діяльності) : навчальний посібник. 4-тє вид., стер. Київ : Знання, 2010. С. 343.
} 
- іншим складником професійної свідомості, який має психологічне походження, варто назвати високу повагу до права та глибоку переконаність у необхідності свідомого виконання його вимог, сприйняття права як найвищої соціальної цінності;

- установка на активну правомірну й професійно значущу поведінку, яка передбачає готовність до виконання будь-якого професійного обов'язку, точне й неухильне застосування вимог правових норм, принциповість у боротьбі з правопорушеннями, прагнення до справедливості, визнання необхідності самовдосконалення тощо.

Ці складові елементи варто вважати визначальними, тому що вони відображають структурні блоки людської свідомості, мають свій зміст і виступають як характерні риси загальної моделі професійної свідомості юристів. Залежно від спеціалізації юридичної професії ця модель може зазнавати певних змін з погляду іiі змісту, але все-таки видається можливим стверджувати про наявність системи загальних вимог щодо свідомості юристів, які й утворюють зміст запропонованої моделі.

Процес формування професійної свідомості й культури юристів відбувається в певному соціальному середовищі, яке так чи інакше здійснює вплив на всі процеси, що відбуваються в ньому. Соціальне середовище за структурою - дуже складне явище, у якому, крім суб'єктів, варто розрізняти засоби, форми, методи, принципи діяльності, причинні зв'язки тощо. Тому доцільним буде розглянути названі фактори в аспекті їх суб'єктивного та об'єктивного впливу.

Серед факторів суб'єктивного порядку, які впливають на формування професійної культури юристів, варто назвати правове виховання, яке здійснюється в різноманітних формах і має на меті безпосереднє втручання

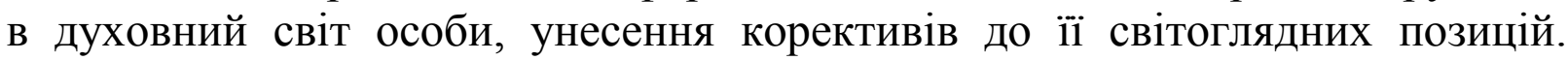
Характерною ознакою суб'єктивного фактору варто назвати безпосередність і цілеспрямованість впливу. До форм правового виховання належать правове навчання, самовиховання, самоосвіта, юридична практика, правова агітація, пропаганда. На практиці ці форми реалізуються у функціонуванні системи юридичної освіти, проведенні науково-практичних семінарів, конференцій, організації стажування, підвищенні кваліфікації, різноманітних способах практичної діяльності юристів.

До суб'єктивного фактору варто також зарахувати умови сімейних відносин; відносин, що склалися в робочому колективі та характеризують моральний мікроклімат колективу; спадкоємність (перейняття) правових цінностей.

Спадкоємність - одна з важливих характеристик суспільного життя в сфері права. Як утілення досягнень людства у сфері права правова культура 
передбачає передачу правових цінностей наступним поколінням. Цей процес поєднує в собі правове виховання та юридичну освіту, однак засвоєння тих чи інших правових цінностей має носити глибоко усвідомлений характер особливо в питаннях рецепції права, євроінтеграційних процесів, запозичення правових інститутів інших держав, має відбуватися їх розумне перенесення на український «грунт» 3 урахуванням національного менталітету й готовності суспільства до таких запозичень.

3 іншого боку, укорінені якісні правові цінності не мають відкидатися лише тому, що розроблені попередніми поколіннями чи іншими країнами. Наприклад, римська цивілістика залишається неперевершеною для сучасного правотворення та практичного застосування цивільного права, а глибина теоретичних узагальнень і висновків видатних римських юристів, ïх мистецтво глибокого наукового аналізу, практичне застосування своїх висновків, оцінок і тлумачень є прикладом і для сучасних юристів. Об'єднуючи Європу на практиці, римське право об'єднувало іiі i в теоретичних пошуках: французька юриспруденція, наприклад, працювала весь час поряд із юриспруденцією німецькою, італійською, мала 3 ними спільну мову, шукала вирішення одних і тих самих проблем. Так виросла на грунті римського права спільна робота всієї європейської юриспруденції, яка продовжувала роботу мислителів античного світу ${ }^{18}$.

Отже, реалізація спадкоємності має відбуватися не просто в передачі цінностей попередніх поколінь як «музейного експонату», а в засвоєнні уроків минулого, недопущенні помилок історії, оволодінні накопиченим досвідом і використанні цього комплексу як основи для розвитку й удосконалення сучасного правового життя.

Серед факторів об'єктивного порядку - економічний і політичний устрій, правова система суспільства, домінуючі в суспільстві політико-правові ідеали, стан правового життя юридичної спільноти тощо. Й об'єктивні, і суб'єктивні фактори за природою $є$ невід'ємними речами, які тісно взаємодіють і доповнюють одне одного.

Високий рівень правового життя юридичної спільноти, ефективність правового регулювання, належний стан законності в суспільстві створюють надійну основу для здійснення ефективного впливу на свідомість представників юридичної професії. При цьому якісний рівень їхньої професійної свідомості й культури зумовлює ефективність функціонування права, стабільність правопорядку, надійність у багатьох сферах соціального життя ${ }^{19}$.

\footnotetext{
${ }^{18}$ Орач С.М., Тищик Б.Й. Основи римського приватного права: навчальний посібник. Львів : Ред.-вид. відділ Львів. ун-ту, 2000. С. 3-4.

${ }^{19}$ Гусарєв С.Д., Тихомиров О.Д. Юридична деонтологія (Основи юридичної діяльності) : навчальний посібник. 4-тє вид., стер. Київ : Знання, 2010. С. 344.
} 
Зазначені фактори формування професійної культури пов'язані 3 питанням аналізу iï мотивації. Мотивація (франц. motivation обгрунтування, від motif - спонукальна причина) - це внутрішній (психологічний) процес виникнення спонукань, що грунтуються на потребах, інтересах, почуттях, емоціях і динаміці їх розвитку через прагнення діяти в наміченому напрямі; результат формування мотиву та обгрунтування на цій основі вольового акту ${ }^{20}$. Мотивація поведінки включає свідомість особи, іiі ставлення до себе, оточуючих, суспільства загалом, чинних у ньому моральних і правових вимог, співставлення з ними наявних прагнень при виборі способів досягнення поставлених цілей. Саме мотивація $\epsilon$ тією спрямовуючою та організуючою силою, що спонукає до конкретної поведінки й діяльності загалом.

Аналізуючи професійну культуру, яка проявляється в конкретних активних діях, необхідно відмітити, що висхідними мотивами професійної поведінки юристів можуть бути не лише їхні власні інтереси, а й потреби соціальних груп і суспільства загалом.

У цьому аспекті цікавими $\epsilon$ результати опитування, проведеного В.А. Леванським та М.Я. Соколовим серед юристів, на основі якого визначено, що типовими мотивами їхньої власної професійної поведінки є: 1) принципова позиція щодо захисту суспільних інтересів; 2) принципова позиція щодо захисту особистих інтересів громадян; 3) принципова позиція, щодо захисту інтересів професійної групи та колективу; 4) ортодоксальноюридична позиція «закон є закон»; 5) професійний інтерес до результатів діяльності; 6) конформна позиція, орієнтована на поведінку громадян; 7) конформна позиція, орієнтована на поведінку юридичної групи; 8) конформна позиція, орієнтована на поведінку керівництва; 9) професійні звички; 10) вузькопрагматична позиція та зацікавленість у «проходженні справи»; 11) страх покарання за недотримання службових обов'язків; 12) острах осуду 3 боку колег, знайомих, родичів; 13) егоцентрична поведінка; 14) безтурботна позиція щодо виконання службових обов'язків; 15) кар'єристська позиція; 16) матеріальна винагорода ${ }^{21}$.

Виходячи 3 результатів опитування, варто наголосити на усвідомленні юристами власної принципової позиції, пов'язаної із захистом суспільних, колективних чи особистих інтересів громадян. Це додатково підкреслює соціальне значення юридичної професії. Саме на основі цього показника громадяни оцінюють їхню роботу й формують власне ставлення як до діяльності державних органів, так і до юристів як соціально-професійної

\footnotetext{
${ }^{20}$ Юридична енциклопедія : у 6 т. / редкол. : Ю.С. Шемшученко та ін. Київ : Укр. енцикл. ім. М.П. Бажана, 1998-2004. T. 3 : K-M. С. 779.

21 Леванский В.А., Соколов Н.Я. Опыт конкретно-социологического исследования и моделирования профессиональной культуры юристов. Lex Russica (Hayчные труды MГЮА). 2006. № 2. С. 258.
} 
групи. Подальші дослідження мотивів поведінки юристів мають вагоме значення для розуміння не лише рушійної, а й регулювальної функції професійної правової свідомості та культури.

\section{ВИСНОВКИ}

Правова культура є системою духовних і матеріальних цінностей права, що $\epsilon$ складником загальної культури й охоплює всю сукупність найважливіших ціннісних компонентів розвитку правової реальності, $€$ однією з категорій загальнолюдських цінностей і невід'ємним компонентом правової держави. В аспекті логічної структури правова культура становить суму об'єктивних за своїм змістом знань про державу і право. За глибиною цих знань виділяють звичайний і професійний (спеціальний) рівні. Перший iз них обмежується загальними знаннями людей про правові явища. Другий формується в осіб, які спеціально займаються правовою діяльністю (юристів). У науковому розумінні професійна правова культура - це правова культура, носіями якої $\epsilon$ правники, котрі професійно займаються юридичною діяльністю та яким властиві більш глибокі юридичні знання.

Правова культура юристів $є$ одним із видів групової професійної культури, яка $\epsilon$ складовим елементом правової культури суспільства загалом, а ключовим критерієм виокремлення цієї соціальної групи $\epsilon$ професійна належність. Термін «професійна» підкреслює більш якісний рівень праці та характер ставлення соціальної групи чи особи до власної трудової діяльності, яка є основним джерелом доходу.

Професійна культура та правова свідомість юристів багато в чому збігаються з поняттям правової культури, що зумовлено правовою сферою їхньої професійної діяльності. Однак не варто повністю ототожнювати ці поняття. У їх співвідношенні можна виокремити фактори, що впливають на формування професійної культури юристів, які розглядаються в аспекті їх суб'єктивного й об'єктивного впливу.

До факторів суб'єктивного належать правове виховання, юридична освіта, способи практичної діяльності юристів; умови сімейних відносин і відносин, що склалися в робочому колективі та характеризують моральний мікроклімат колективу, спадкоємність (перейняття) правових цінностей.

До факторів об'єктивного порядку належать економічний і політичний устрій, правова система суспільства, домінуючі в суспільстві політикоправові ідеали, стан правового життя юридичної спільноти тощо. Ці об’єктивні, й суб'єктивні фактори за природою є невід'ємними речами, які тісно взаємодіють і доповнюють одне одного. 


\section{АНОТАЦІЯ}

У роботі проводиться аналіз поняття й сутності професійної культури юристів, узагальнюються фактори ії формування. Підвищення ролі права в процесі розбудови демократичної, соціальної, правової держави та становлення громадянського суспільства висуває підвищені вимоги до рівня підготовки, правової культури та правосвідомості юристів. Чітке з'ясування стану й рівня зрілості професійної культури юристів - необхідна умова ефективної правової політики.

Дослідження професійної культури юристів становить інтерес з погляду 3'ясування специфіки формування, функціонування та розвитку культури великої соціальної групи в державі, об’єднаної суттєвими професійними інтересами. Важливо враховувати й той факт, що відсутність у юристів правової культури не лише ускладнює боротьбу з правопорушеннями, а й може стати однією з причин їх скоєння.

Ефективне правове регулювання суспільних відносин, удосконалення чинного законодавства в рамках євроінтеграції, посилення боротьби зі злочинністю. Злагоджене функціонування всіх елементів механізму правового регулювання суттєво залежить від професійної правової культури юристів.

Фактори, що впливають на формування професійної культури юристів, розглядаються в аспекті їх суб'єктивного й об'єктивного впливу, однак за природою вони взаємопов'язані, тісно взаємодіють і доповнюють одне одного.

\section{ЛІТЕРАТУРА}

1. Бурдоносова М.А. Методологічні особливості дослідження професійної культури юристів. Публічне право: науково-практичний юридичний журнал. 2015. № 4 (20). С. 261-267.

2. Великий енциклопедичний юридичний словник / за ред. акад. НАН України Ю.С. Шемшученка. 2-ге вид., переробл. і доповн. Київ : Юридична думка, 2012. $1020 \mathrm{c}$.

3. Гусарєв С.Д., Тихомиров О.Д. Юридична деонтологія (Основи юридичної діяльності) : навчальний посібник. 4-тє вид., стер. Київ : Знання, 2010. 495 c.

4. Калітенко О.М. Окремі проблеми правового статусу насцитуруса за чинним законодавством України. URL: http://dspace.onua.edu.ua/bitstream/ handle/11300/7992/ilovepdf_com-7-9.pdf?sequence=1\&isAllowed=y （дата звернення: 02.11.2020).

5. Кримінальний процесуальний кодекс України від 13.04.2012 № 4651-VI. База даних «Законодавство Украӥни» / Верховна Рада України. URL: https://zakon.rada.gov.ua/go/4651-17 (дата звернення: 01.11.2020). 
6. Леванский В.А., Соколов Н.Я. Опыт конкретно-социологического исследования и моделирования профессиональной культуры юристов. Lex Russica (Hayчные труды МГЮА). 2006. № 2. С. 230-269.

7. Макаренко Л.О. Теоретико-методологічні аспекти пізнання та формування правової культури : дис. ... докт. юрид. наук : 12.00 .01 / Інститут держави і права імені В.М. Корецького НАН України. Київ, 2019. 423 с.

8. Оніщенко Н.М. Сприйняття права в умовах демократичного розвитку: проблеми, реалії, перспективи : монографія / відп. ред. Ю.С. Шемшученко. Київ : Юридична думка, 2008. 320 с.

9. Орач Є.М., Тищик Б.Й. Основи римського приватного права : навчальний посібник. Львів : Ред.-вид. відділ Львів. ун-ту, 2000. 238 с.

10. Правила Арбітражного інституту Стокгольмської торговельної палати від 01.01.1988. База даних «Законодавство України» / Верховна Рада України. URL: https://zakon.rada.gov.ua/go/752_050 (дата звернення: 01.11.2020).

11. Сливка С.С. Філософсько-правові проблеми професійної культури юриста : автореф. дис. ... докт. юрид. наук : 12.00 .12 / Національна юридична академія України ім. Ярослава Мудрого. Харків, 2002. 32 с.

12. Соколов Н.Я. Профессиональная культура юристов. Понятие. Сущность. Содержание. Москва : Проспект, 2014. 320 с.

13. Цивільний кодекс України від 16.01.2003 № 435-IV. База даних «Законодавство України» / Верховна Рада України. URL: https://zakon.rada.gov.ua/go/435-15 (дата звернення: 02.11.2020).

14. Чупринський Б.О. Формування професійної культури майбутніх юристів: філософсько-правове дослідження : автореф. дис. ... канд. юрид. наук : 12.00.12 / Львів. держ. ун-т внутр. справ. Львів, 2010. 20 с.

15. Юридична енциклопедія : у 6 т. / редкол. : Ю.С. Шемшученко та ін. Київ : Укр. енцикл. ім. М.П. Бажана, 1998-2004. Т. 1-Т. 6 : іл.

\section{Information about author: Burdonosova M. A.,}

Candidate of Law, Associate Professor, Associate Professor at the Department of Constitutional and Administrative Law of the Faculty of Law Institute of Management, Technology and Law of the State University of Infrastructure and Technologies 19, I. Ogienko str., 19, Kyiv, 03049, Ukraine 